NBER WORKING PAPER SERIES

\title{
AGEING AND WELFARE-STATE POLICY MAKING: MACROECONOMIC PERSPECTIVE
}

\author{
Assaf Razin \\ Alexander Horst Schwemmer \\ Working Paper 29162 \\ http://www.nber.org/papers/w29162 \\ NATIONAL BUREAU OF ECONOMIC RESEARCH \\ 1050 Massachusetts Avenue \\ Cambridge, MA 02138 \\ August 2021, Revised August 2021
}

All sources of funding disclosed. The views expressed herein are those of the authors and do not necessarily reflect the views of the National Bureau of Economic Research.

NBER working papers are circulated for discussion and comment purposes. They have not been peer-reviewed or been subject to the review by the NBER Board of Directors that accompanies official NBER publications.

(C) 2021 by Assaf Razin and Alexander Horst Schwemmer. All rights reserved. Short sections of text, not to exceed two paragraphs, may be quoted without explicit permission provided that full credit, including $(\subset$ notice, is given to the source. 
Ageing and Welfare-State Policy Making: Macroeconomic Perspective Assaf Razin and Alexander Horst Schwemmer

NBER Working Paper No. 29162

August 2021, Revised August 2021

JEL No. F3,H0

\begin{abstract}
$\underline{\text { ABSTRACT }}$
It has been well recognized that population ageing could generate structural changes centered around the dwindling labor force, on one hand, and the expanding dependency on the generosity of the welfare state, on the other hand. Ageing-related welfare state policy entails both fiscal issues and migration issues. The paper employs a general-equilibrium model with a policymaking focus, to help understand the mechanism governing the provision of social benefits, labor income taxation, capital income taxation, migration curbs on low skilled and high skilled, driven by the ageing of the population. Greater generosity of the welfare state comes together with policy of a more liberal migration policy - incentive compatible with the interests of the majority voters.
\end{abstract}

Assaf Razin

Eitan Berglas School of Economics

Tel Aviv University

Tel Aviv 69978

ISRAEL

and Cornell University and CEPR

and also NBER

razin@tauex.tau.ac.il

Alexander Horst Schwemmer

Department of Economics

Ludwig-Maximilians-Universität

Geschwister-Scholl-Platz

Munich, 80539

Germany

alexander.schwemmer@outlook.com 


\title{
Ageing and Welfare-State Policy: Macroeconomic Perspective
}

\author{
Assaf Razin \\ The Eitan Berglas School of Economics \\ Tel Aviv University \\ Tel Aviv, 69978, Israel \\ Email: razin@tauex.tau.ac.il \\ Website: $\underline{\text { https://www.tau.ac.il/ razin }}$ \\ and \\ Alexander Schwemmer \\ Department of Economics \\ Ludwig-Maximilians-Universität \\ Geschwister-Scholl-Platz Munich, 80539, Germany \\ alexander.schwemmer@outlook.com
}

August 15, 2021 


\section{Abstract}

It has been well recognized that population ageing could generate structural changes centered around the dwindling labor force, on one hand, and the expanding dependency on the generosity of the welfare state, on the other hand. Ageing-related welfare state policy entails both fiscal issues and migration issues. The paper employs a general-equilibrium model with a policy-making focus, to help understand the mechanism governing the provision of social benefits, labor income taxation, capital income taxation, migration curbs on low skilled and high skilled, driven by the ageing of the population. Greater generosity of the welfare state comes together with policy of a more liberal migration policy -- incentive compatible with the interests of the majority voters.

\section{Introduction}

Ageing of the population is a fundamental factor which help determine the generosity of the welfare state. Germany, and EU member states, serve as a real world reference point. In 2010, the proportion of people aged 65 and older constituted in the core EU countries 20.8 percent in Germany, 20.3percent in Italy, 16.8 percent in France, and 16.6 percent in the UK (United Nations, 2013).As a benchmark, this share is only 13.1 percent in the US. Although the population in the US is getting older, and its numbers are growing more slowly, than in the past, 
the demographic future for the US is younger than that of the core EU countries. In particular, the US population is projected to grow faster and age more slowly than the populations of its major economic partners in Europe. Figure 1 describes the ageing patterns of Germany (the largest EU economy) compared to the US as a benchmark, in terms of the age dependency ratio.

Figure 1: Old age dependency ratio (\% of working-age population): Germany vs. United States

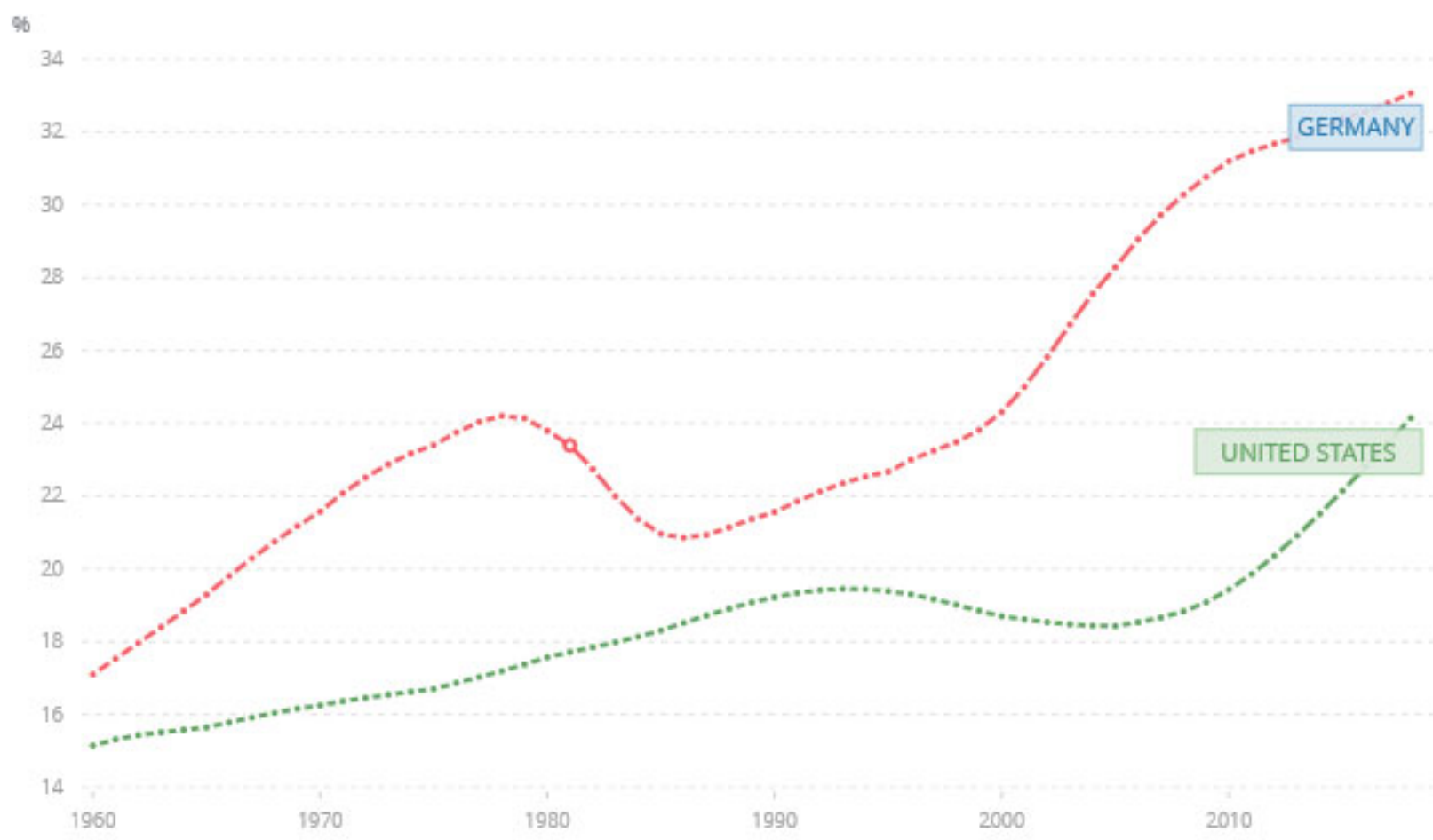

Source: The World Bank.

Concerning welfare-state generosity in advanced economies, Figure 2 compares the EU 20 nondefense government spending per capita, in percent of GDP, with US’s per GDP spending, over 
the years 1995-2018. . EU spending significantly exceeds the US spending, year by year, indicating that the EU welfare state is overwhelmingly more generous.

Figure 2: General Government Expenditure (Excluding Defense) in percentage of GDP

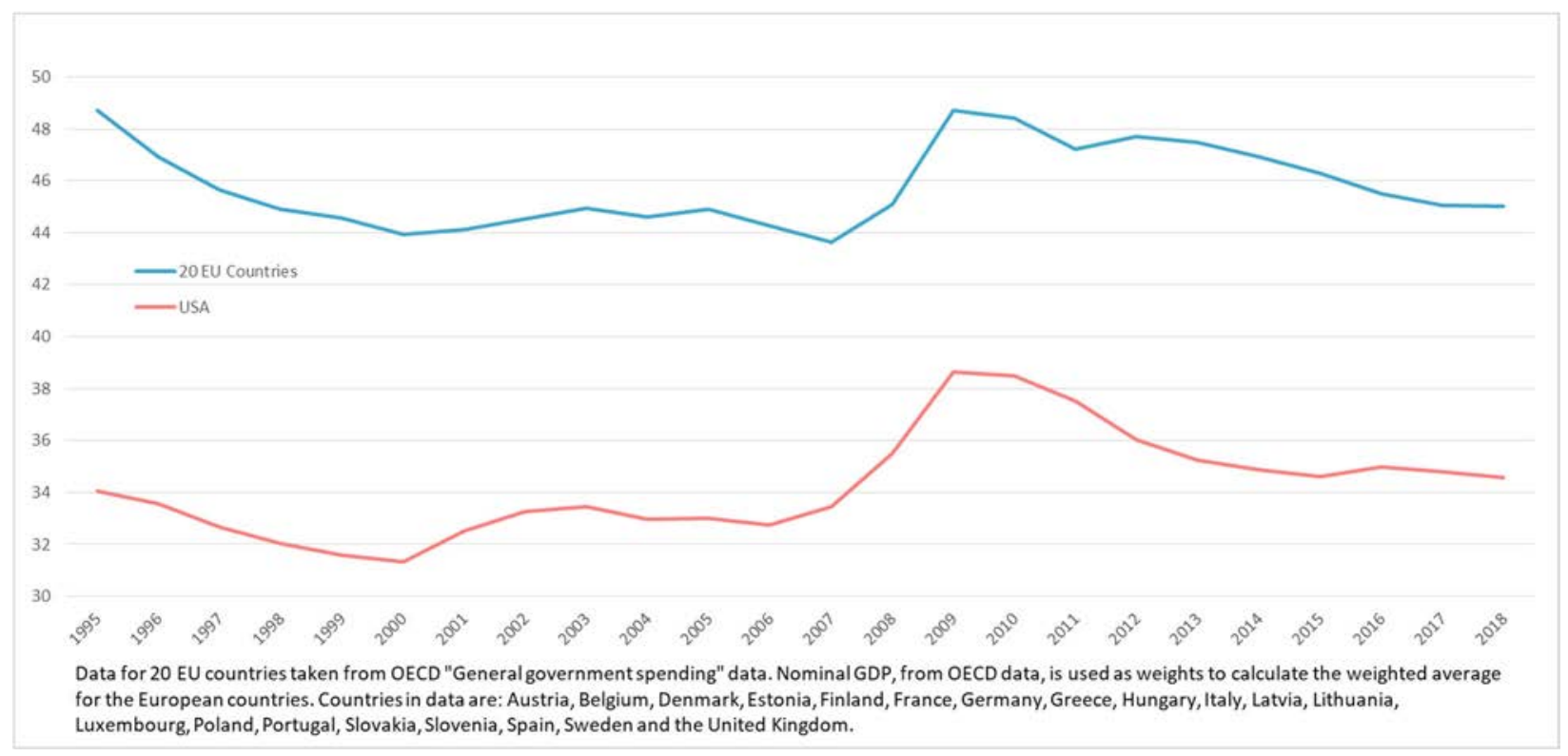

Milton Friedman famously quipped: "free immigration and a welfare state are incompatible". ${ }^{1}$ To mitigate adverse macroeconomic impact of ageing on the labor force, fiscal prospects depend on two forces. The first is the potential for capital deepening through capital imports. The second is through immigration. Whereas capital imports are typically not administratively restricted, labor mobility is constrained by policy. The immigration constraints are typically rooted in the political-economy sensitivities in the host countries. One major reason for immigration restrictions is the negative on native-

\footnotetext{
${ }^{1}$ For analyses of the interaction between migration and welfare-state generosity see, Razin and Wahba (2014) and Razin (2021).
} 
born employment and wages. ${ }^{2}$ Another reason for the rise of policy-based restrictions on immigration is the advent of a generous welfare state.

Welfare-state voters are motivated not only by how migration affects their wage income. That is, since the welfare state redistributes income from the rich to the poor, unskilled migrants, over lifetime, are net beneficiaries of the welfare state. In contrast, skilled (rich) migrants are in general net contributors. Consequently, under free migration, the migrant skill composition is tilted towards the unskilled; whereas under controlled migration regime, the skill composition is skewed towards the skilled. ${ }^{3}$

However, voters are driven also by how migration bears on the social insurance system, when they retire, become unemployed, etc. Migration effects on the social insurance system are common to voter preferences, regardless of skills. From the public-finance point of view, native-born voters opt for highskilled migrants to come on shore; whereas, for the unskilled to stay away, to mitigate the fiscal burden on them. Therefore, notwithstanding the common interests in social insurance, the different income effects of migration on voters, every welfare state unavoidably adopts migration regulations and restrictions ${ }^{4}$. As native-born population ageing progress, the welfare state needs more immigrants to sustain the social insurance system. There is a growing share voters depends on social benefits. Consequently, these voters would benefit from loosening restrictions on migration; both high skilled and low skilled.

\footnotetext{
${ }^{2}$ Results of empirical studies on low-skill migration effects on wages are mixed. Findings in Borjas (2003) and Dustmann et al. (2017) among others, it is in contrast with results in Card (2001, 2005), Foged and Peri (2016), and Ottaviano and Peri (2012), who document that immigrants have a negligible, or even positive, impact on native-born earnings.

${ }^{3}$ See Appendix 1 for a relevant literature survey.

${ }^{4}$ See Razin et al. (2002a, 2002b).
} 
The purpose of this paper is to provide a macroeconomic framework to understand the effects of population ageing on policies relating to welfare-state policy; with migration policy as an integral part. A parsimonious model allows a comparison across different welfare-state and migration-policy regimes. Key policy variables are the provision of social benefits, determined jointly with skill-based migration policy. Furthermore, provision of social benefits, wage income tax, capital income tax, international capital mobility, international trade, are endogenously being determined in this generalequilibrium setup. Policy-related feature involved is the economic interests of various income groups as ageing progresses.

The paper is organized as follows. Section II presents the main blocks of the model. Section III explains the patterns which emerge from the simulations. Section IV concludes.

\section{Model}

We set up a two-period political-economy policy model, with ageing as a driving force, capturing skill based immigration policy jointly and welfare-state redistribution policy, that are determined through majority voting. The supply side features a standard Heckscher-Ohlin model ${ }^{5}$. In a low-ageing state

\footnotetext{
5 Using public opinion polls conducted in the United States, Steve and Slaughter (2001) and O'Rourke (2003), find indirect support for hypotheses derived from the Heckscher-Ohlin trade model. Specifically, they find that there is a robust skills cleavage over immigration policy, with highly skilled workers being less likely to support restricting immigration policies and lowskilled counterparts more likely to do so; and these effects of immigration on workers at different skill levels are consistent with the model. Their findings suggest 'the potential for immigration politics to be connected to the mainstream redistributive politics over which political parties often contest elections.
} 
the economy is a relatively labor abundant, importing capital from the rest of the world. Increased ageing makes the economy becomes relatively more labor-scarce which triggers the export of domestic capital to the rest of the world. Ageing therefore directly affect factor prices and changes tax bases. The government provides a uniform social benefit. Capital income tax is proportional whereas the average rate of the labor income tax progresses from low-skilled wage to high-skilled wage. Ageingrelated dwindling of the labor force drives up demand for foreign labor in the form of skilled and lowskilled immigration. International capital mobility generates Laffer-Curve effects of tax policies on tax revenue that is needed for providing social benefits. A low capital tax rate creates high volume of capital imports, so that taxing foreigners help raise the tax revenue. But, excessively high capital tax rate generates diminishes capital imports and the tax revenue.

\section{II.1 Income groups}

In order to consider redistribution issues, which are at the heart of the welfare state, we assume that there minimally are two types of individuals -- low skilled-poor (indexedu) and high skilled -rich (indexed $s$ ). The workers have two types of skills-low (l) and high (h). There are three types of factors of production—capital $(\mathrm{K})$ high-skilled labor $\left(L_{H}\right)$, and low-skilled labor $\left(L_{H}\right){ }^{6}$

6 Confining considerations to factor rewards under the standard complementarity—substitution specification of production functions, low skill labor, and capital, benefit from high skill immigration, whereas high skill labor loses. However, such narrow benefit-lose calculation abstracts from the general-equilibrium effect factor allocation across sectors, international capital flows and from the fiscal aspects associated with the welfare state. 
Each high-skill individual is endowed with $\bar{x}_{s}$ units of good $\mathrm{x}$, and $\bar{y}_{s}$ units of good $\mathrm{y}$, respectively, in the first period; a low-skill individual is endowed with only $\theta<1$ units of a skilled individual's wealth endowment. Thus, a skilled-rich individual enjoys both higher initial endowment (“wealth”), and higher labor market skill than the unskilled-poor individual.

Ageing leads to increasing dependency ratio - the ratio of retirees to workers- is the main driving force in our analysis.

To capture the essence of ageing, we assume an idiosyncratic shock in the second period so that, with certain likelihood the individual retires from work.

The overall size of the initial native-born population is normalized to one, where a proportion $\lambda$ of the population is of high skill and a proportion $1-\lambda$ is of low skill. We denote by $m_{s}$ the number of high-skill migrants and by $m_{l}$ the number of low-skill migrants. We denote the number of highskill immigrants, $m_{S}$, and low-skill immigrants, $m_{L}$.

\section{II.2 Dependents}

The welfare state provides universal social benefits, paid by tax on labor income and tax on capital income. There are two periods. We assume that everyone works in the first period. As for the second period, with a probability $\emptyset$, an individual is out of work, earning no wage income. The individual draws on the earned income which is saved from the first period. We label this individual as dependent, because relative to others in the same skill group, the individual spending draws more the welfare-state social transfers. To capture dependency on the social insurance through retirement, unemployment, disability, etc., we assume that there is an individual idiosyncratic shock. The probability of non-work 
realization is also the share of dependents in the population. Because migrants typically come in young and productive, the non-working shock does not apply to them.

\section{II.3 Immigration}

Immigrants, who bring with them no capital, consume only in the second period, and their utility function is given by:

$u=\left(c_{x 2}\right)^{\alpha}\left(c_{y 2}\right)^{1-\alpha}+d B^{\gamma}$

Consumption functions are:

(1a) $c_{x m s 2}=a\left(1-t_{L S}\right)\left(w_{H}\right)$,

and

(1b) $c_{y m S 2}=(1-a)\left(1-t_{L S}\right)\left(w_{H} / \mathrm{p}\right)$

(1c) $c_{x m L 2}=a(1-b)\left(1-t_{L L}\right)\left(w_{L}\right)$, 
and

$$
c_{y m L 2}=(1-a)(1-b)\left(1-t_{L L}\right)\left(w_{L} / \mathrm{p}\right)
$$

Where $t_{L S}$ and $t_{L L}$ denote wage proportional wage tax rates on high-skill and low-skill, respectively.

The exogenously given pair $u_{H}^{*}, u_{L}^{*}$ of utility levels attained by S-individuals and L-individuals, respectively, in foreign residence. The number of high skilled immigrants depends positively on the foreigndomestic utility differential, $u_{s m}-u_{S}^{*}$; and number of low skilled immigrants depends positively on the foreign-domestic utility differential $u_{L m}-u_{L}^{*}$.

Under the free migration regime, the number of migrants are determined as follows.

$$
\begin{gathered}
m_{H}=Z_{H}\left(u_{m H}-u_{H}^{*}\right)^{Z_{H}} \quad \text { with } Z_{H}>0,0<z_{H}<1 . \\
m_{L}=Z_{L}\left(u_{L m}-u_{L}^{*}\right)^{z_{L}} \quad \text { with } Z_{L}>0,0<z_{L}<1 .
\end{gathered}
$$

For consistency, under a controlled-migration regime, $m_{H}$ and $m_{L}$ are policy controlled variables. The migration quotas must be chosen so that

$$
u_{m H}-u_{H}^{*}<\left(\frac{m_{H}}{z_{H}}\right)^{-z_{H}} \text {, and } u_{m L}-u_{L}^{*}<\left(\frac{m_{L}}{z_{L}}\right)^{-z_{L}} \text {. }
$$

\section{II.4 Production and investment}


To enable us to consider trade in goods we assume that there minimally are two tradable goods ( $\mathrm{x}$ and y). In the absence of uncertainty and differentiated products, each sector will either export or import its standard product, but not both at the same time. World prices of $x$ and $y$ are exogenously given for our small open economy with good x serving as a numeraire, whose price is normalized to one, and the world price of $\mathrm{y}$ is denoted by $\mathrm{p}^{*}$. There is an impediment to trade in goods. Specifically, goods can be exported, but again only at some border related friction cost (e.g., country specific standards, regulations, etc.). For concreteness of the notation, we consider y as an export good. A similar and straightforward notation applies when $\mathrm{x}$ is the export good. ${ }^{7}$ We denote this cost per unit of price by $\delta_{y}$, so that the domestic price of the export good y is

$$
p_{t}=\frac{p^{*}}{\left(1+\delta_{y}\right)}
$$

A representative firm produces well $g$ according to a constant-returns-to scale technology:

$$
g=A_{g} F_{g}\left(K_{g}, L_{H g}, L_{H g}\right)=A_{g} K_{g}^{\alpha_{g}} L_{H g}^{\rho_{g}} L_{L g}^{1-\rho_{g-\alpha g}}, \quad g=x, y,
$$

Where, $K_{\mathrm{g}}$ is the input of physical capital, and $L_{H g}$ is high-skill labor, and $L_{L g}$ is low-skill labor, used in the respective production process. $A_{g}>0$ Is a total factor productivity coefficient, and $\alpha_{g}, \rho_{g}$, and $1-\rho_{g}-\alpha_{g}$ are, respectively, the capital, high-skill labor, and low-skill labor shares in the sector producing $g$.

\footnotetext{
${ }^{7}$ By the Lerner Symmetry proposition, any wedge between the domestic and the world prices applied to importable goods, is equivalent to a wedge between world and domestic prices applied to exportable goods.
} 
Capital is employed together with labor in the first period with output generated in the second period. We assume that labor is paid in the second period, at the end of the production process.

Capital $(K)$ is a composite good, produced in the first period is of a variable mix of $x_{k}$ and $y_{k}$, according to:

$$
K=x_{k}^{\beta} y_{k}^{1-\beta} \text {, where } 0<\beta<1 \text {. }
$$

To find the cost minimizing mix of $\mathrm{x}$ and $\mathrm{y}$, of which a unit of capital $(\mathrm{K})$ is composed of, one, has to solve the following problem:

$$
\min _{(x, y)}\left(x_{k}+p_{1} y_{k}\right)
$$

Subject to:

$$
x_{k}^{\beta} y_{k}^{1-\beta} \geq 1,
$$

Where $p_{t}$ is the domestic price of $y$ in period $t=1,2$.

Solving this problem yields also the unit price $p_{k}$ of capital as

$$
\text { (7) } \quad p_{k}=D p_{1}^{1-\beta} \text {, }
$$

where $D=\left(\frac{1-\beta}{\beta}\right)^{\beta}+\left(\frac{\beta}{1-\beta}\right)^{1-\beta}$. 
Demands for labor and capital are given, respectively, by the marginal productivity conditions in both sectors. Note that because labor and capital move freely between the two sectors, then the factors of production earn the same remuneration across sectors, that is:

$$
w_{H}=\left(\rho_{x}\right) A_{x} k_{H x}^{\alpha_{x}} l_{L x}^{1-\rho_{x-} \alpha_{x}},
$$

(8a)

(8b)

$$
w_{H}=p_{2}\left(\rho_{y}\right) A_{y} k_{H y}^{\alpha_{y}} l_{L y}^{1-\rho_{y-} \alpha_{y}}
$$

$$
\begin{aligned}
& w_{L}=\left(1-\alpha_{x}-\rho_{x}\right) A_{x} k_{H x}^{\alpha_{x}} l_{L x}^{-\rho_{x-} \alpha_{x}} \\
& w_{L}=\left(1-\alpha_{y}-\rho_{y}\right) A_{y} k_{H y}^{\alpha_{y}} l_{L y}^{-\rho_{y-} \alpha_{y}}
\end{aligned}
$$

$$
\begin{aligned}
& p_{k}(1+r)=\alpha_{x} A_{x} k_{H x}^{\alpha_{x}-1} l_{L x}^{1-\rho_{x-} \alpha_{x}}, \\
& p_{k}(1+r)=\quad p_{2} \alpha_{y} A_{y} k_{H y}^{\alpha_{y}-1} l_{L y}^{1-\rho_{y-} \alpha_{y}},
\end{aligned}
$$

Where $k_{g}$ is the capital- labor ratio in sector $g$, that is $k_{H g}=\frac{K_{g}}{L_{H g}} ; l_{L g}=\frac{L_{L g}}{L_{H g}} ; w_{H}$ is high-skill wage rate, paid in the second period (after the completion of the production process); and $w_{L}$ is low-skill wage rate, paid in the second period after the completion of the production process. Note that for simplicity we assume that capital fully depreciates at the end of the production process. 


\section{II.5 Saving behavior}

We denote by $c_{g i 1}$ the consumption of $\operatorname{good} \mathrm{g}=\mathrm{x}, \mathrm{y}$ by an individual of type $\mathrm{i}=\mathrm{u}$, $\mathrm{s}$ in period $\mathrm{t}=$ 1,2. All native-born individuals have identical preferences, given by

$$
u_{i}=\left(c_{x i 1}{ }^{a} c_{y i 1}{ }^{1-a}\right)^{b}\left(c_{x i 2}{ }^{a} c_{y i 2}{ }^{1-a}\right)^{1-b}+d B^{\gamma}
$$

Where, $0<\mathrm{a}<1,0<\mathrm{b}<1, \mathrm{~d}>0, \gamma>0$, and $B$ is a uniform social benefit (provided in an equal amount to all individuals), assumed (for simplicity) to be provided in the second period only. This social benefit captures the various ingredients that a welfare state provides, such as health services, education, in-kind transfers, etc. Note that the social benefit is not a perfect substitute to private consumption ${ }^{8}$.

The consumption basket remains the same across period 1 and 2 . Therefore, we can aggregate consumption goods into a consumption composite:

$C_{t}=C_{x t}^{a} C_{y t}^{1-a}, \mathrm{t}=1,2$

8 In our model, the redistribution made by the welfare state is in the form of an in-kind benefit. There are other aspects of the social insurance system that we abstract from. For example, in Europe the welfare system is more in the tradition of Beveridge (based on universal at benefits). In some non-European countries, the system is mainly Bismarkian (based on benefits related to past contributions). Since social contributions are related to individual incomes, the more Beveridgean welfare systems have a higher implicit income redistribution. See Cremer and Goulão (2014). 
The composite price is $p_{t}=\Gamma_{p} p_{x t}^{a} p_{y t}^{1-a}$

With,

$\Gamma_{P}=\frac{1}{a^{a}(1-a)^{1-a}}, \quad, \mathrm{t}=1,2$

The (two-state) idiosyncratic shock $\emptyset$, which occurs in the second period, is indexed $\epsilon$, where, $\epsilon=W$, if the individual works, or $\epsilon=R$, if the individual retires from work; with the probability of the nonworking state, $\emptyset$, and the probability of the working state, 1 - $\emptyset$.

The Individual household I seeks to maximize the expected utility

$$
U_{i}=C_{1 i}+\beta \mathbf{E}_{\epsilon}\left[\log C_{2 i}(\epsilon)\right]
$$

Subject to

$C_{1 i}+S_{1 i}=\bar{x}_{i}+p \bar{y}_{i}$, and

$$
\begin{gathered}
S_{i}\left[1+\left(1-t_{k}\right) r\right]+\left(1-t_{L i}\right) w_{i}=p_{2} C_{W 2}, \text { if } \epsilon=W \\
S_{i}\left[1+\left(1-t_{k}\right) r\right]=p_{2} C_{R 2} \text {, if } \epsilon=R,
\end{gathered}
$$

Where, the proportional tax on labor income is $t_{L i}$, and the capital income of residents and foreigners (from domestic sources only) is taxed at a flat rate $t_{k} ; C_{t i}$ represents period- $t$ consumption spending, $S_{i}$ denotes period-1 domestic saving of individual I, and $\mathbf{E}_{\epsilon}$ denotes the expectation operator for the distribution function of the non-working shock $\epsilon ; \quad ; I=S$, L.. 


\section{II.6 Capital Flows}

Recall that the welfare-state fiscal prospects depend on two factors, in order to mitigate adverse macroeconomic impact of ageing. The first is the potential for capital deepening. The second is increased immigration. Domestic capital deepening depends in and out capital flows.

As usual, capital flows are driven by net-of-tax rates of return. Capital does flow internationally, but at some cost $\delta_{k}>0$ per unit. The net return on investing into domestic capital is $1+r\left(1-t_{k}\right)$ for investors, where $\mathrm{r}$ is the domestic interest rate. A domestic individual who invests abroad can thus gain only $1+\left(1-t_{K}^{*}\right) r^{*}-\delta_{k}$, where $r^{*}$ is the world interest rate and $t_{K}^{*}$ is the tax rate, levied abroad under a source-based taxation. In a small, open economy context, the two (exogenous) variables $t_{K}^{*}$ and $r^{*}$ play an equivalent role, where the only relevant variable is $R^{*}=$ $\left(1-t_{K}^{*}\right) r^{*}$, which is the net of tax international interest rate. We assume that the cost of capital flows applies symmetrically to foreign investors, i.e. their return on investment in the domestic country is given by $1+\left(1-t_{K}\right) r-\delta_{k}$, where investing abroad yields a return $R^{*}$.

The small open economy exports capital in case:

$$
\left(1-t_{K}\right) r=R^{*}-\delta_{k}
$$

This means that $\left(1-t_{K}\right) r-\delta_{k}<R^{*}$, and therefore foreigners do not invest in the domestic economy. 
Similarly, the small open economy imports capital in case:

$$
\left(1-t_{K}\right) r-\delta_{k}=R^{*}
$$

This means that $\left(1-t_{K}\right) r>R^{*}-\delta_{k}$, and therefore the residents of the small open economy do not wish to invest abroad. ${ }^{9}$

\section{II.7 Current Account}

First-period current account surplus is given by:

$$
(1-\lambda)\left(\bar{x}_{u}+p_{1} \bar{y}_{u}\right)+(\lambda)\left(\bar{x}_{s}+p_{1} \bar{y}_{s}\right)-(1-\lambda)\left(c_{x u 1}+\right.
$$

$$
\begin{gathered}
\left.\left.p_{1} c_{y u 1}\right)\right)+(\lambda)\left(c_{x s 1}+p_{1} c_{y s 1}\right)+p_{k}\left(K_{x}+K_{y}\right)=\left[(1-\lambda) S_{u}+(\lambda) S_{s}\right]- \\
p_{k}\left(K_{x}+K_{y}\right) .
\end{gathered}
$$

\footnotetext{
${ }^{9}$ Ageing-related decline in the labor force brings about two reinforcing factors which effect capital outflows: the "international interest-differential effect", and the "relative factor endowment" effect.
} 
Note that when the country exports capital (that is, $(1-\lambda) S_{u}+(\lambda) S_{s}>p_{k}\left(K_{x}+K_{y}\right)$ ), then it incurrs the cost of $\delta_{k}$ on its capital exports. Conversely, when foreigners invest in the domestic economy (that is, $(1-\lambda) S_{u}+(\lambda) S_{s}<p_{k}\left(K_{x}+K_{y}\right)$ ), then the country pays foreiners only $1+\left(1-t_{k}\right) r$, because they are taxed on their income originating in the domestic economy; foreigners bears the friction cost $\delta_{k}$ in this case.

Second period resource constraint is given by:

$$
\begin{aligned}
& (1-\lambda)\left(c_{x u 2}+p_{2} c_{y u 2}\right)+(\lambda)\left(c_{x s 2}+p_{2} c_{y s 2}\right)+m_{H}\left(p c_{x m s 2}+c_{y m s 2}\right) \\
& +m_{L}\left(\left(p c_{x m L 2}+c_{y m L 2)}+d c_{d e p}+\left(1+m_{L}+m_{H}+d\right) B\right.\right. \\
& =F_{x}\left(K_{x}, L_{x}\right)+p_{2} F_{y}\left(K_{y}, L_{y}\right)+\left[(1-\lambda) S_{u}+() S_{s}-p_{k}\left(K_{x}+K_{y}\right)\right] I_{C F}
\end{aligned}
$$

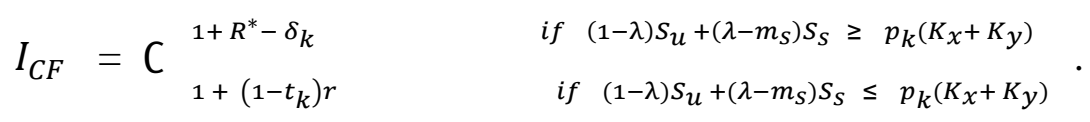

\section{II.8 Policy Instruments}


Finally, consider the government, which is active in a balanced-budget way only in the second period. Its budget constraint is:

$$
\begin{aligned}
& \left(1+m_{H}+m_{L}+d\right) B=t_{L L}\left(w_{L}\left((1-\lambda) \emptyset+m_{L}\right)+t_{L S} w_{S}\left(\lambda \emptyset+m_{S}\right)+\right. \\
& t_{k} r p_{k}\left(K_{x}+K_{y}\right) .
\end{aligned}
$$

Note that the government taxes capital income of both domestic residents and foreigners which originates in the domestic economy, $r p_{k}\left(K_{x}+K_{y}\right)$. This means that when saving of domestic residents exceeds domestic investment, $p_{k}\left(K_{x}+K_{y}\right)$, with the excess invested abroad, then this excess is not taxed at home. Conversely, when savings of domestic residents fall short of domestic investment, $p_{k}\left(K_{x}+K_{y}\right)$, with the shortage financed by foreigners, then this shortage is taxed by the domestic government.

The available policy instruments are the number of high-skilled migrants, $m_{H}$, the number of low -skilled migrants, , $m_{L}$, the labor income tax rates, $t_{L S}$ and $t_{L L}$ (proportional wage tax rates on high-skill and low-skill, respectively), the capital income tax rate, $t_{k}$, and the scale of the social benefit, $B$. Labor income tax is progressive (measured by the difference in the average rate differential $\left.t_{L S}-t_{L L}>0\right)$, whereas capital income tax $\left(t_{k}\right)$ is proportional.

Note also that the government taxes capital income of both domestic residents and foreigners which originates in the domestic economy, $r p_{k}\left(K_{x}+K_{y}\right)$. This means that when saving of 
domestic residents exceeds domestic investment, $p_{k}\left(K_{x}+K_{y}\right)$, with the excess invested abroad, then this excess is not taxed at home. Conversely, when savings of domestic residents fall short of domestic investment, $p_{k}\left(K_{x}+K_{y}\right)$, with the shortage financed by foreigners, then this shortage is taxed by the domestic government.

We abstract from a tax on the initial endowments because these are in fixed supply at the beginning of the first period, and a tax on them is not distortive; it will tend to be extremely high. Furthermore, when the low-skill form the majority, they will tax them at a rate of $100 \%$. For a similar reason, we abstract also from a tax on consumption (VAT) because it is equivalent to a tax on wages (which are taxed directly in our model), and a tax on the initial endowments (see, for instance, Frenkel, Razin and Sadka (1991)).

\section{Comparing Policy-Making Regimes}

In what follows, the main results are summarized in table1 and 2., each followed by graphs of the numerical simulations, to provide details ${ }^{10}$.

\section{III.1 Ageing and Social Benefit provision}

\section{Table 1: Effects of Increase Ageing on Social Benefit Provision}

\footnotetext{
${ }^{10}$ See Appendix 2 for the simulation parameter values.
} 


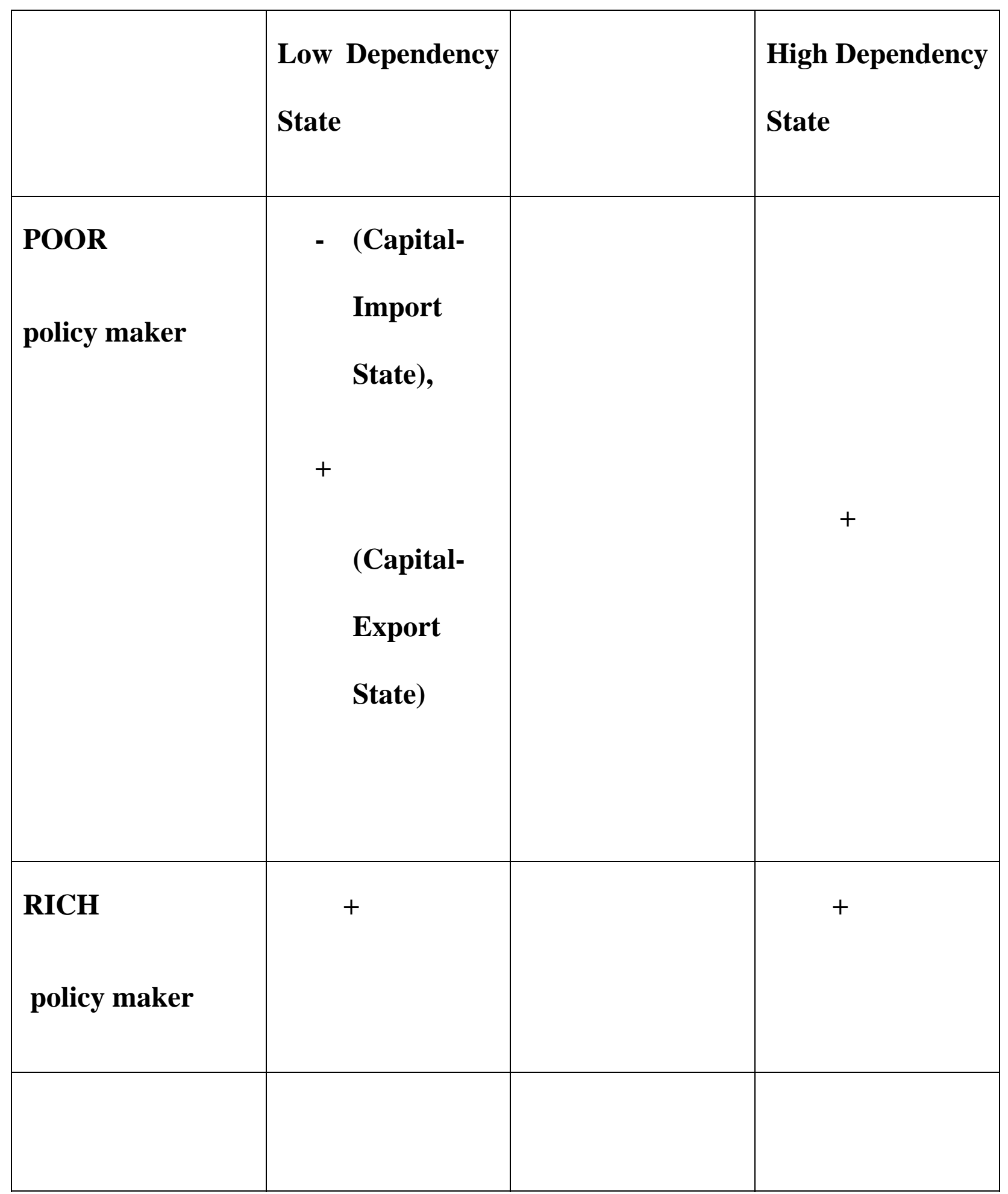

The Table demonstrates that ageing boosts, or lessens social-benefit provision according to the identity of the policy maker representing either the rich or the poor, the greater need for the social benefit when the probability of retirement grows, the ability to tax the foreigners who invest in the 
domestic economy, and the ability o a rich policy maker to tax the wage of low-skill labor and vice versa, for the case of a poor policy maker. To finance dwindling tax revenue when more people retire high-skilled naturally attempt to impose on the low skill higher wage tax to finance the ageing-related dwindling tax revenue when the high skilled are in a political power. They definitely are not interested tin a higher tax on capital that will reduce their net income from savings. When the low skill are in a political power, they impose on the high skill higher wage tax to finance the dwindling tax revenue when more people retire, and the increased provision of social benefit (per capita) because of greater income needs when they retire.

The capital import state the capital tax burden is shared with foreigners. Imposing tax on capital income has a Laffer-Curve effect on capital-income tax revenue.

If the POOR are policy makers, ageing also increases the provision of social benefit (per capita) in the high dependency state because of greater income needs when they retire. To finance the dwindling tax revenue when more people retire, they impose on the high skill higher wage tax to finance the dwindling tax revenue when more people retire. In the capital import state some of the capital tax burden is shared with foreigners. Imposing tax on capital income has a Laffer-Curve effect on capital-income tax revenue. In the low-dependency state overlapping with capital import state, the POOR will need to tax their wage income to sustain more generous retirement incomethey cost exceeds the benefit. The RICH who are providing less generous retirement transfers than the POOR (and need smaller tax revenue) are on the more significant revenue -increasing segment of the capital tax Laffer curve.

To gain further insight into the results of the simulations it is worth to note that if the ageing parameter (the $\varnothing$-parameter) attains low values and the labor force is relatively large, the country 
imports capital from the rest of the world; whereas for large values of the ageing parameter (the $\emptyset$-parameter), the country become a capital exporter.

Figure 3: Provision of social benefits

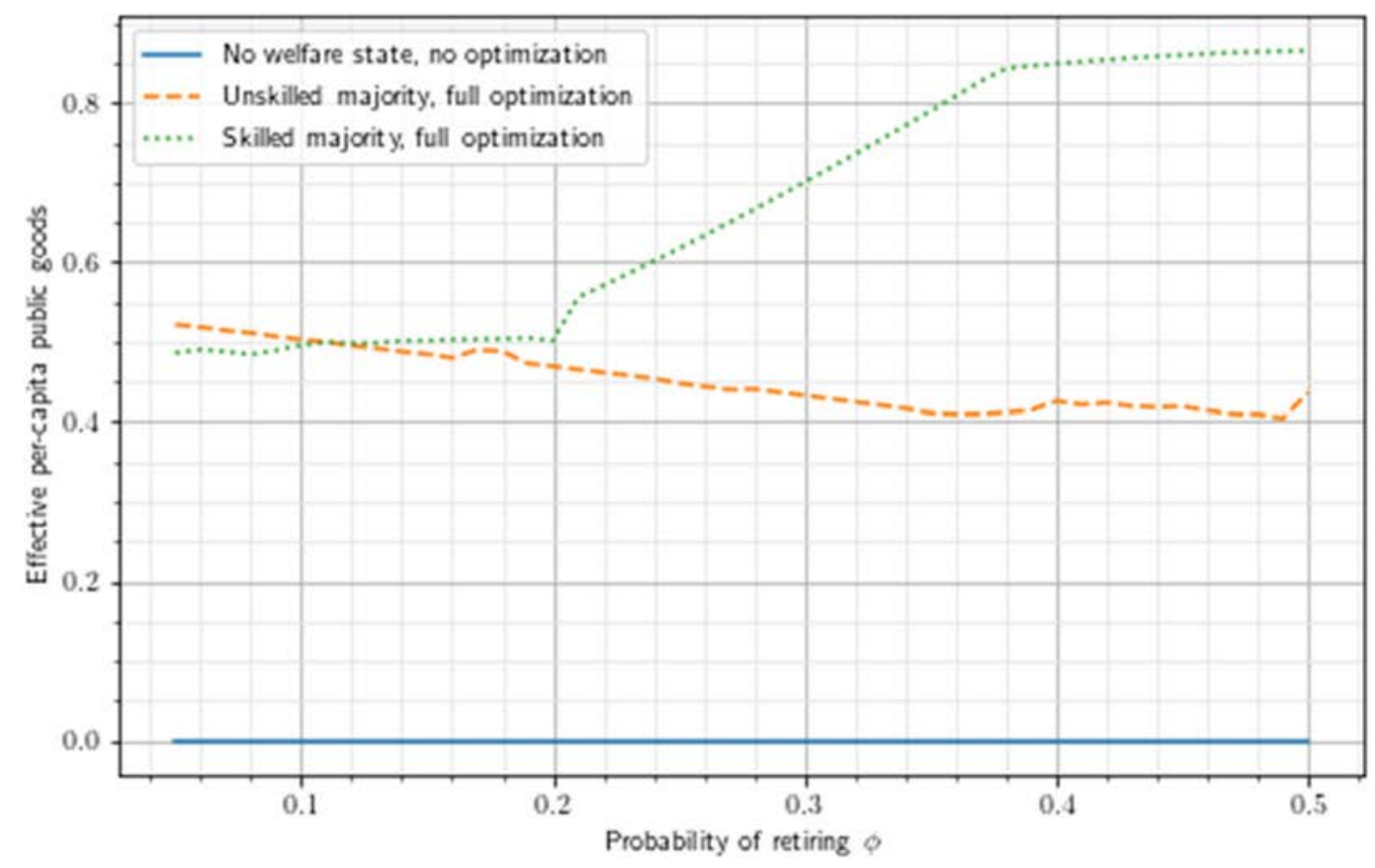

Note: For $\varnothing$-parameter values falling short of 0.2 the economy imports capital. For $\varnothing$-parameter values exceeding 0.35 the economy exports capital. For $\emptyset$-parameter values in between 0.2 and 0.35 the economy is in financial autarky. For the model's parameter values, see Appendix.

Figure 3 shows that, 
1. The high-skilled regime provides greater social benefits than the low-skilled regime (under capital imports triggered by low values of the ageing parameter (the $\emptyset$-parameter), socialbenefit provision is approximately similar for both regimes).

2. For high ageing state, increasing the ageing parameter (the $\varnothing$-parameter) raises social-benefit provision in both the high-skilled regime and the low-skill regime (but, ageing lowers the provision in the low-skilled regime with low range of values values of the $\emptyset$-parameter) .

Ageing reinforce the demand for greater provision of social benefits, and strengthen these tendencies. In the following Figures we compare the high skilled regime policies with the low-skilled regime policies, through varying the retirement-likelihood parameter, $\emptyset$.

Figure 4: Capital income tax: high skilled majority vs. low-skilled majority 


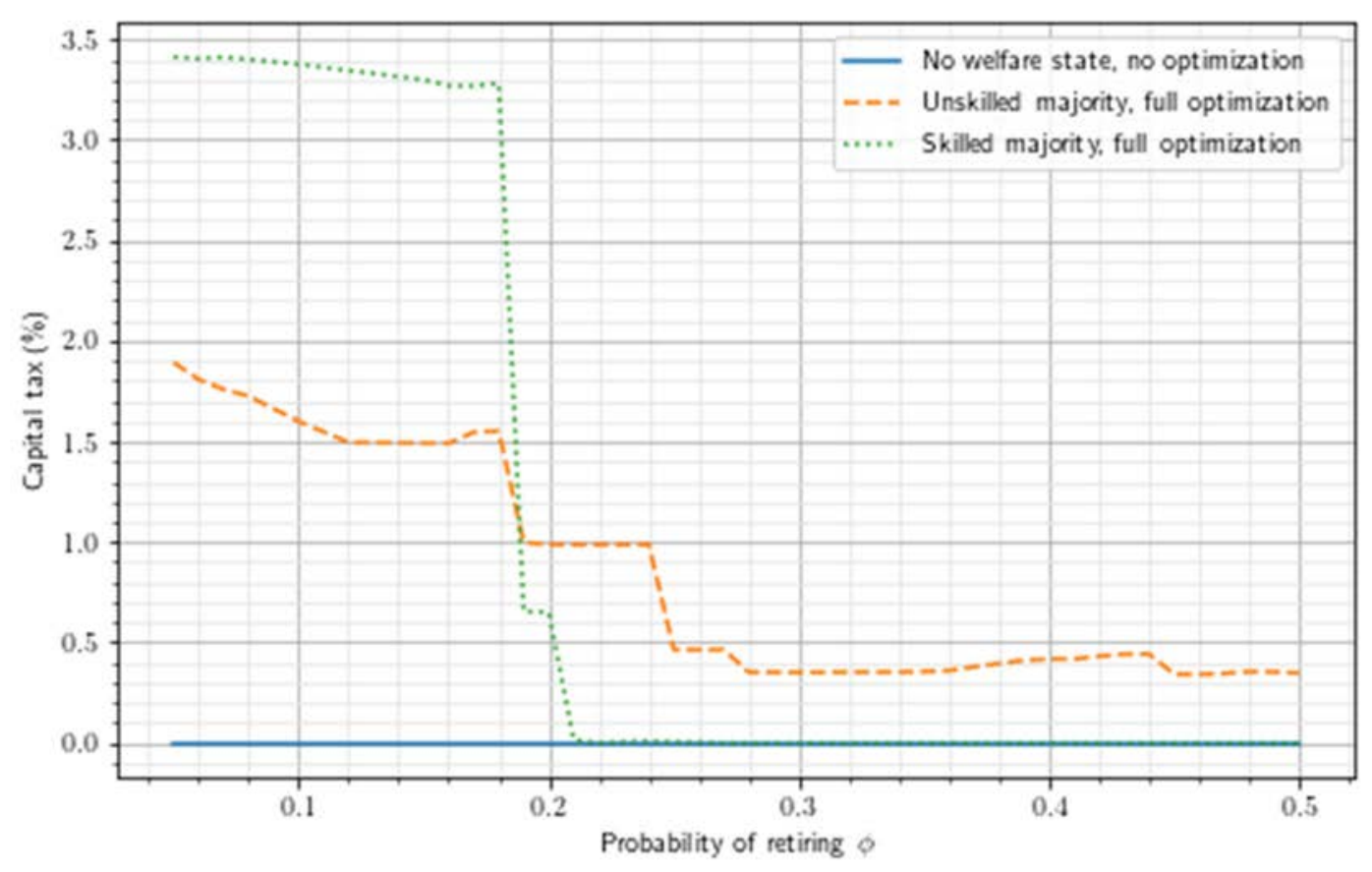

Note: For $\emptyset$-parameter values falling short of 0.2 the economy imports capital. For $\emptyset$-parameter values exceeding 0.35 the economy exports capital. For $\emptyset$-parameter values in between 0.2 and 0.35 the economy is in financial autarky. For the model's parameter values, see Appendix.

Figure 4: demonstrates that, indeed, ageing drives down taxation of capital income.

1. The capital tax rate set by the high-skilled, rich, policy making is higher than the rate set by the low-skilled majority if the country is capital importer. The capital tax rate is set equal to zero set by the high-skilled majority if the country is capital exporter.

2. Increasing the ageing parameter (the $\emptyset$-parameter) lowers the capital tax rate set by the high-skilled majority if the country is capital exporter. Increasing the $\emptyset$-parameter lowers the rate of tax on capital by the low-skilled majority, regardless of whether the country exports or imports capital. 
Figure 5: low-wage tax rate: high skilled majority vs. low-skilled majority7

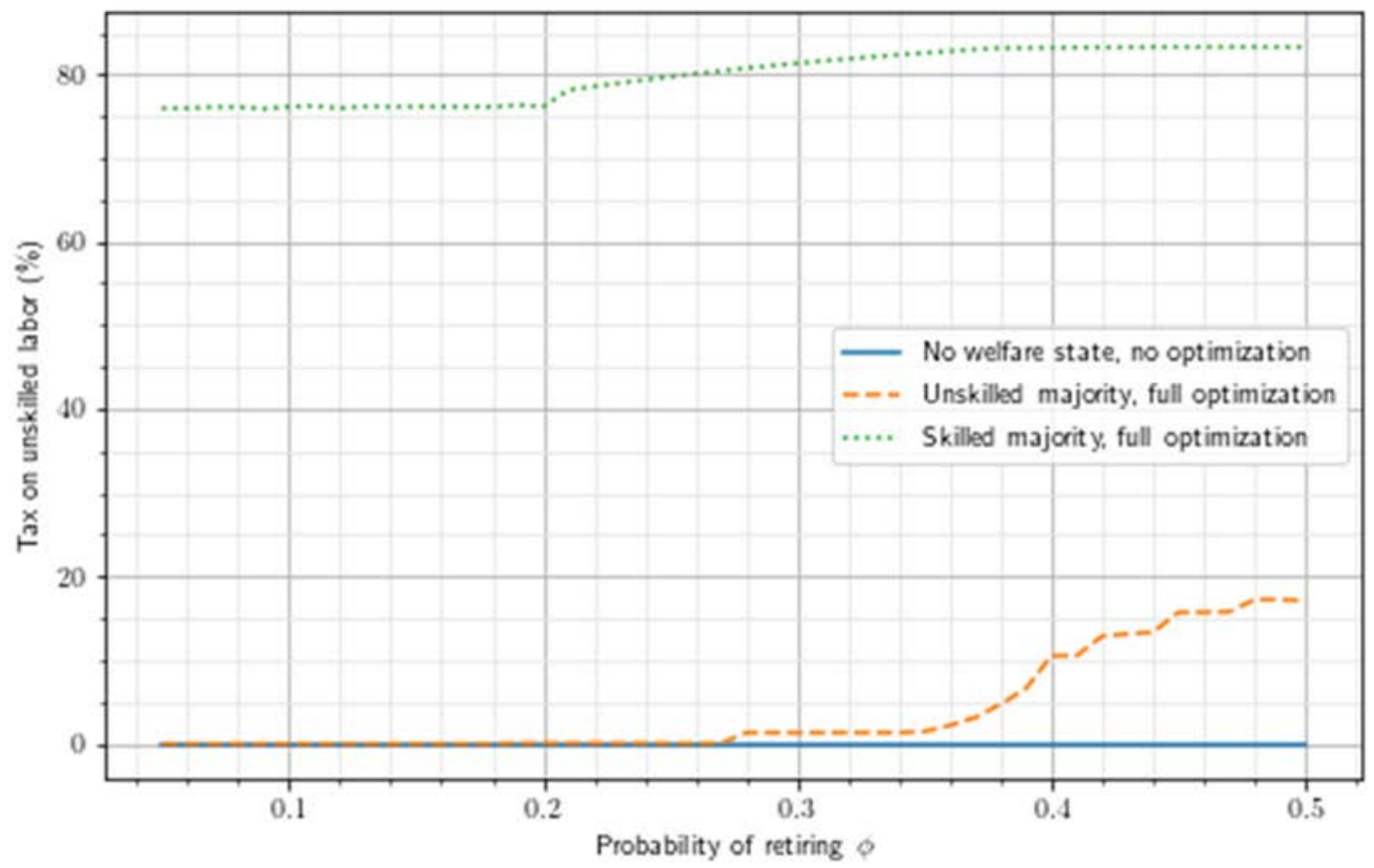

Figure 5 demonstrates that,

1. The low-wage tax rate set by the high-skilled majority is higher than the rate set by the low-skilled majority.

2. Increasing the $\emptyset$-parameter raises the low-wage tax rate under both the high-skilled and low-skilled regimes. 
Figure 6: High-wage tax rate: high skilled majority vs. low-skilled majority

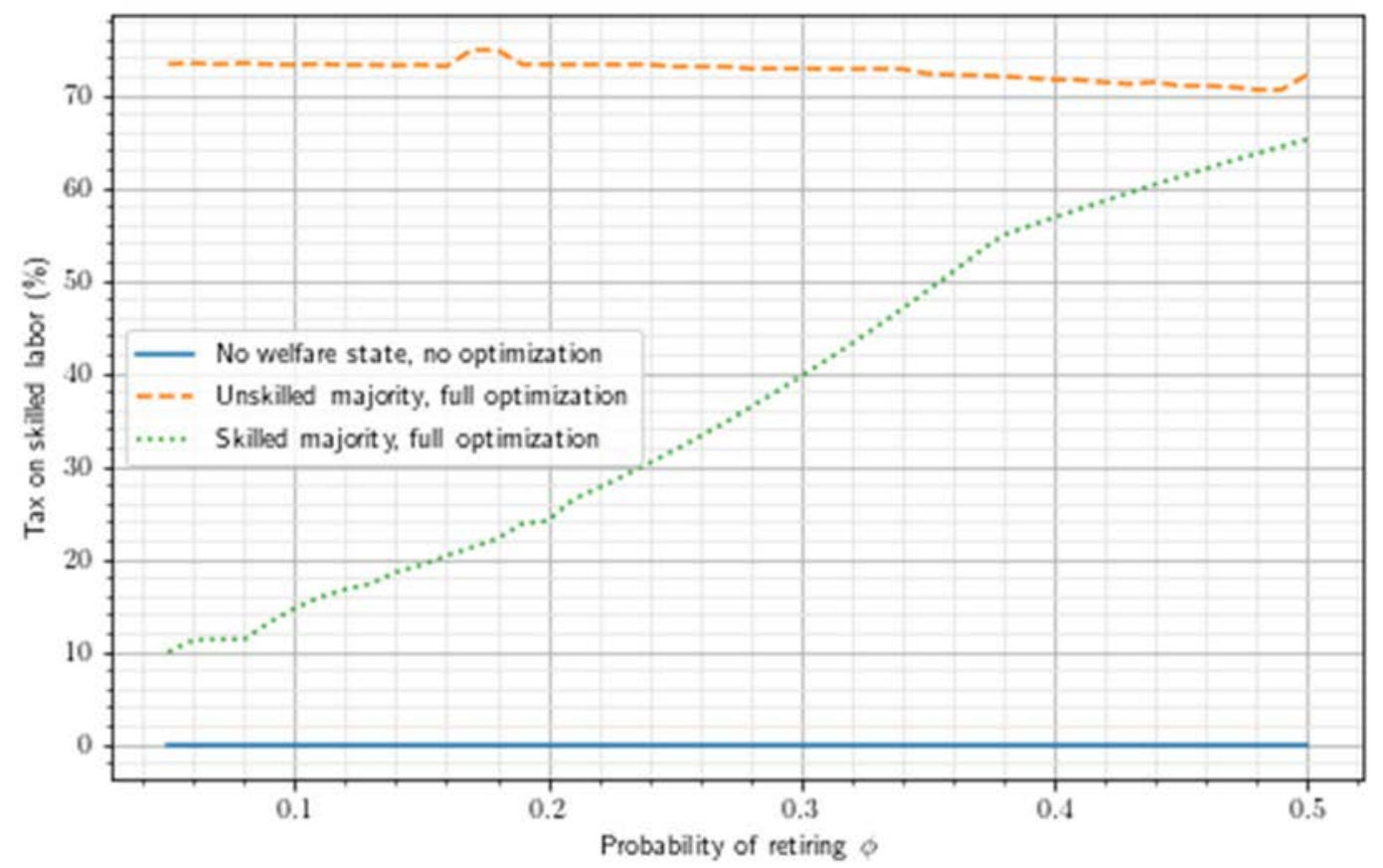

Note: For $\varnothing$-parameter values falling short of 0.2 the economy imports capital. For $\varnothing$-parameter values exceeding 0.35 the economy exports capital. For $\emptyset$-parameter values in between 0.2 and 0.35 the economy is in financial autarky. For the model's parameter values, see Appendix.

Figure 6 demonstrates that,

1. The high-wage tax rate set by the high-skilled majority is lower than the rate set by the low-skilled majority.

2. Increasing the $\emptyset$-parameter raises the high-wage tax rate by the high-skilled but lowers the rate set by low-skilled regime. 


\section{III.2 Ageing and Migration Policy}

Main effects of ageing on migration policy are summarized in Table 2.

Table 2: Increased Ageing and Skill-based Migration Numbers

\begin{tabular}{|c|c|c|}
\hline Migration/ageing & $\begin{array}{c}\text { Low-Ageing } \\
\text { state }\end{array}$ & $\begin{array}{c}\text { High- Ageing } \\
\text { state }\end{array}$ \\
\hline $\begin{array}{l}\text { Number of Low - } \\
\text { Skill Migrants }\end{array}$ & $\begin{array}{l}\text { S-regime } \\
\text { Zero B regime } \\
\text { > U-regime }\end{array}$ & $\begin{array}{l}\text { S-regime > } \\
\text { U-regime > } \\
\text { Zero B regime }\end{array}$ \\
\hline $\begin{array}{l}\text { Number of High- } \\
\text { Skill Migrants }\end{array}$ & $\begin{array}{l}\text { S-regime }< \\
\text { Zero B regime < } \\
\text { U-regime }\end{array}$ & $\begin{array}{l}\text { S-regime }<\mathrm{U} \text { - } \\
\text { regime }<\text { Zero } \\
\text { B regime }\end{array}$ \\
\hline & & \\
\hline
\end{tabular}


Note: S-regime refers to the regime where rich are the policy makers; U-regime refers to the regime where the poor are the policy makers; and, Zero B regime refers to the regime with zero provision of social benefits.

When ageing of the native population rises, the dwindling labor force requires drives up demand for migrants. The consequent rise in the welfare state generosity strengthens this force. If the rich are in charge of the migration policy making, in both the high-ageing state and the low-ageing state they are biased towards relying on low skill migrants more than on the competing high-skill labor. If the poor are in charge of the migration policy making, in both the high-ageing state and the low-ageing state they are biased towards relying more on high skill migrants more than on the competing low-skill labor. Interestingly, in the low-ageing state, the no-welfare state regime migration policy is purely based on substitution-complementarity consideration for the labor market migration effects, the Zero-B regime separates the S-regime and the U-regime in terms of migrant numbers.

Figure 7: low-skilled-migration quota: high-skilled majority and low-skilled majority 


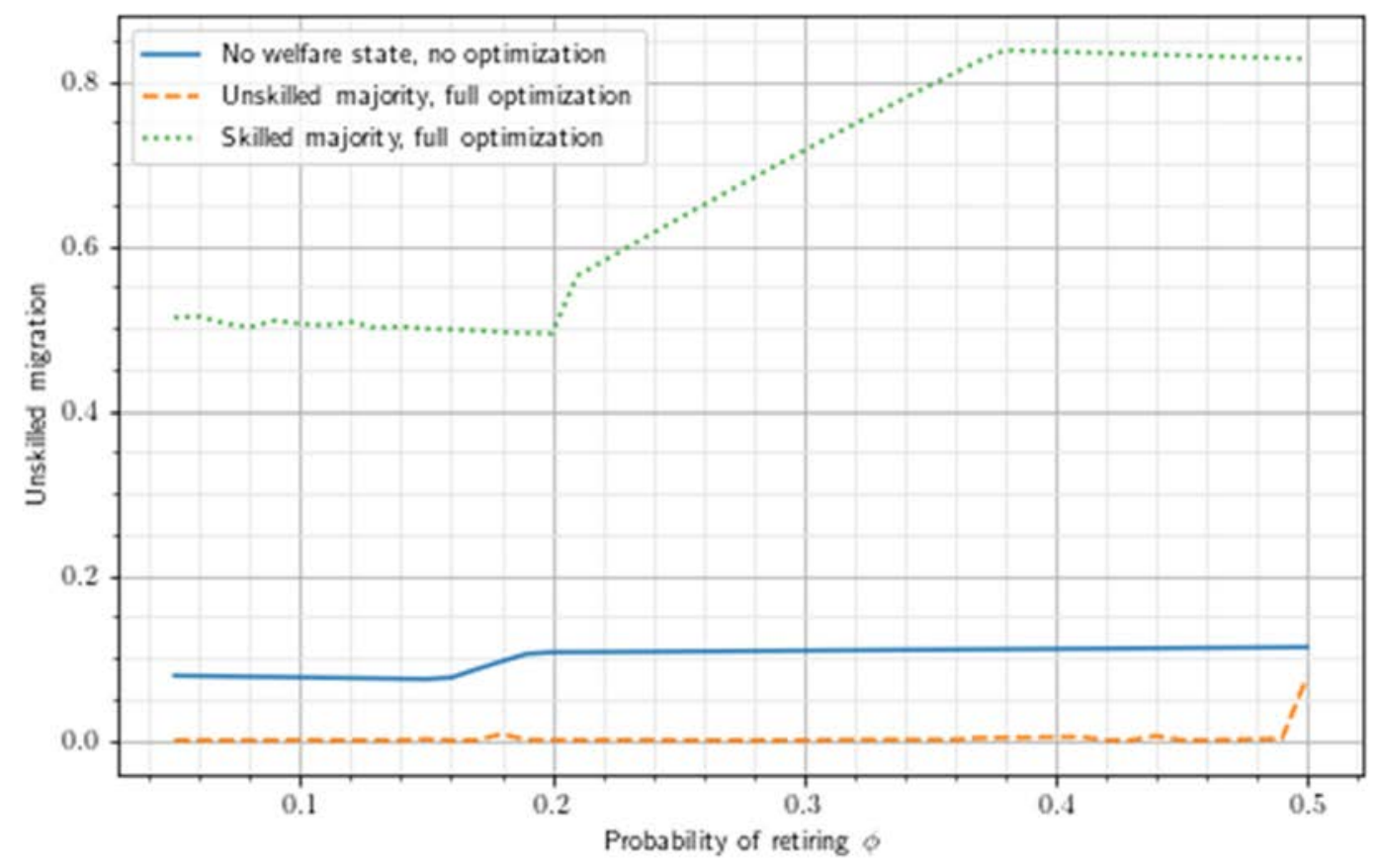

Note: For $\emptyset$-parameter values falling short of 0.2 the economy imports capital. For $\emptyset$-parameter values exceeding 0.35 the economy exports capital. For $\emptyset$-parameter values in between 0.2 and 0.35 the economy is in financial autarky. For the model's parameter values, see Appendix.

Figure 7 shows that,

1. Low skill in- migration numbers are larger under high-skill, rich, policy making then under low-skill, poor, policy making; whereas the numbers under no-social benefit regime take an intermediate position in the ranking. 
2. The high-skilled set high migration quotas to low-skilled migrants, whereas the lowskilled set the quota equal to zero.

1. Raising the ageing parameter (the $\emptyset$-parameter), drives up the low-skill migration quota under the high skill, rich, policy regime; whereas under the policy making set by the lowskill poor the migration quota increses with ageing for high values of the ageing parameter when the scarce-labor effect becomes binding.

Figure 8: high-skilled-migration quota: high skilled majority and low-skilled majority

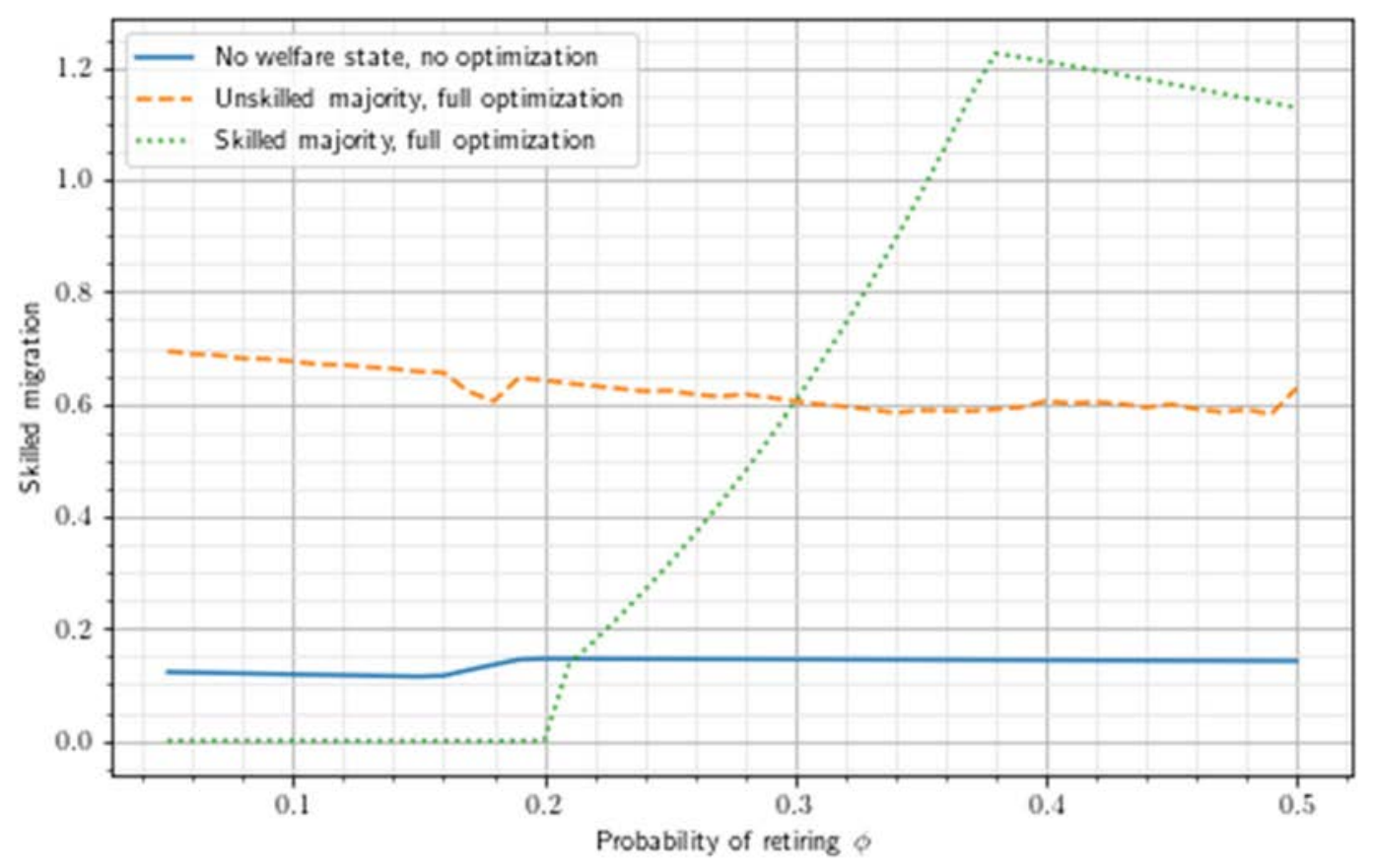

Note: For $\emptyset$-parameter values falling short of 0.2 the economy imports capital. For $\emptyset$-parameter values exceeding 0.35 the economy exports capital. For $\emptyset$-parameter values in between 0.2 and 0.35 the economy is in financial autarky. For the model's parameter values, see Appendix. 
Figures 8 shows that,

1. High skill in- migration numbers are smaller under high-skill, rich, policy making then under low-skill, poor, policy making; whereas the numbers under no-social benefit regime take an intermediate position in the ranking, for low levels of the ageing parameter (the $\emptyset$-parameter) when the country is a capital importer. However, when the country becomes labor scarce, because of high ageing (and it becomes capital-exporter), the migration numbers change: under high-skill, rich, policy making they are larger compared to those set under low-skill, poor, policy making, Under no-social benefit regime these numbers are the lowest.

2. The quota for high-skilled migration set under the high-skilled regime is zero and the quota set by the low-skilled regime is positive if the country imports capital; If the country exports capital, the quota set by the high-skilled regime exceeds the quota set by the lowskilled regime.

3. Increasing the ageing parameter (the $\emptyset$-parameter) lowers the high-skilled migration quota set by low-skilled regime; increasing the $\emptyset$-parameter lowers the high-skilled migration quota set by the high-skilled regime once the country becomes capital exporter. 


\section{Concluding Remarks}

The paper employs a general equilibrium policy-making model to understand how migration quotas of low skilled and high skilled, provision of social benefits, labor income taxation, capital income taxation, are endogenously driven by population ageing.

Low ageing evolution correlates with a relatively labor-abundant country (low retirement) turns into labor-scarce country (high retirement). Parallel to the evolution of the labor force, a capital-importer

country (high rate of return) becomes capital-exporter (low rate of return). Greater ageing-related demand for social benefits is balanced against the rising cost of labor income taxation, and capital income taxation.

Population ageing involves also social policy restructuring. Ageing is a particularly pressing issue in countries with a pay-as-you-go system, where pensions are directly financed through social contributions of the working age population. The public pension scheme and the health insurance system will be responsible for a large part of increases in future public debt. To assure the sustainability of the social insurance system, a gradual increase in the statutory retirement age might be inevitable. Public debt issues are not picked up by the present two-period model, like the one in the present paper. The dynamics of ageing and the provision of social benefits, in a public debt dynamic set up, is a subject of future research.

\section{Appendix 1: Macro Literature on Migration Policy}

In general, a change in the share of high- skilled migrants in the total number of migrants affects the utility level of the decisive voter through three channels. First, an increase in the skill-share raises the economy’s labor productivity and thereby its capacity to raise tax revenues. This, in turn, raises its 
ability to provide social benefits, per capita. Second, an increase in the migrant skill-share, which evidently raises the supply of high-skilled labor relative to the supply of unskilled labor, depresses the skill premium in the labor market. Third, raising the tax rate is distortionary, moving the economy below its production possibility frontier. If the decisive voter is low killed, both of the above effects raise his utility. Thus, a low-skilled voter would like to set the skill composition of migrants at its maximum. If, however, the decisive voter is high-killed, whereas the first effect raises his utility, the second effect lowers it. This means that the share of high-skilled migrants preferred by the decisive skilled voter is typically lower than that preferred by the decisive low-skilled voter. Under a policy-controlled migration regime, if the decisive voter is a low-skilled worker, an increase in the tax rate (which thereby raises the provision of social benefits) would benefit a low- skill migration policy unchanged. Because, it is always set at the maximum possible limit, constrained by the magnitude of the tax distortionary effect. However, if the decisive voter is a high-skilled worker, an increase in the tax rate (thereby raising the provision of social benefits) will change the policy concerning the skill composition of migrants in the direction towards a larger share of skilled migrants. The reason for this is that when the tax rate is higher, the redistribution burden upon a high- skilled decisive voter increases. That is, allowing an additional skilled migrant can ease this rise in the fiscal burden. In both cases, if the decisive voter is high-skilled worker or the low-skilled worker the skill-mix of migrants is higher than what is expected to be if migration-controlled policy is absent. This effect is called a fiscal-burden effect of the welfare state generosity on the skill-composition of migrants an increase in the generosity of the welfare state in the destination country under free migration would mean greater fiscal burden falling on the highskilled migrants and more redistribution that benefits low-unskilled migrants, thereby diminishing the skill composition of migration. This effect is called a magnet effect of the welfare state generosity on the skill-composition of migrants. Razin and Wahba (2014) put these effects into an empirical validation, 
using the inter- and intra-migration flows in the European Union as a central identification strategy. To this end, Razin and Wahba (2014) decompose bi-lateral migration sample into three groups as follows. Group A (EUR to EUR) contains only the source-host pairs of countries, which allow free mobility of labor between them, according to the Schengen agreement. Razin and Wahba (2015) find that a more generous welfare state tilts the skill composition downward under free migration and upward under policy- controlled migration. Regardless whether migration is free or controlled, a higher Gini generates greater income distribution and consequently more skill-biased immigration. Under a free-migration regime, the skill-composition of immigration depends also on the skill- distribution of the labor force in the sending and receiving countries. In a seminal paper, George Borjas (1987) derived the conditions under which immigrants are negatively, or positively, selected in terms of skills. Borjas (1987) analyzes some conditions which favor negative selection—meaning that immigrants are drawn disproportionately from the bottom half of the skill distribution. They are: high returns to skills in the sending country relative to the receiving country, and migration costs that are proportional to worker productivity (for example, costs that have an iceberg form), which combine to give less skilled workers a relatively strong incentive to migrate. On the other hand, migration costs that are fixed in nature and a marginal utility of income that is not strongly decreasing favor positive selection of immigrants in terms of skills (Grogger and Hanson 2011), in which case immigrants are drawn more heavily from the top half of the skills distribution In Razin, Sadka and Swagel (2002 a,b ) the dependency effect of unskilled migrants on the welfare-state policy depends on two contrasting driving forces. On the one hand, the effect is negative because a rise in the dependency ratio increases the fiscal burden on the median voter. On the other hand, the dependency-ratio effect on policy is positive to the extent that the median voter preference shifts towards the group of voters who are net beneficiary of the welfare state. In the present context of two skill levels, the effects of a rise in the dependency ratio on the welfare-state generosity 
policy is negative if the high skill are in the majority, and positive if the low skill are in the majority Interest-group arguments in political science date back more than a century. From the pioneering works of Arthur F. Bentley (1908), V.O. Key, Jr. (1942) to David B. Truman (1951). Group models of politics search for propositions about how and when individuals coordinate their activities and engage in collective behavior (Olson 1971). Work in this vein commonly attempts to link policy demands to concrete (or expected) gains and losses of identifiable sub-groups of the electorate, and to the bargains and concessions, they produce in pluralistic political systems. Interest-group approaches have focused on a broad array of groups positioned for or against immigration (Freeman (1995); Gimpel and Edwards (1999); Haus (1995); Joppke (1998)).

\section{Appendix 2: Simulation model and Parameter values}

To simplify the model in the text, the simulation model has a layered production structure with three inputs, two intermediary goods and one final good in each period. This is without much loss of generality, but simplifies the analysis. The final good in each period serves this purpose.

The final good is produced by a Cobb-Douglas production function. Individuals start with an endowment $\theta_{i}$ of the final good, $I=1,2$. The capital good is produced one-to one from the final good, thus reducing the need to track another production function that is not at the core of the analysis.

Preferences are specified as

$$
u\left(c_{i, t}, b\right)=\frac{c_{i, t}^{1-\sigma}-1}{1-\sigma}+d_{g} \frac{(b)^{1-\gamma_{g}}-1}{1-\gamma_{g}}
$$

Provision of social benefit $b$ is:

$$
b=\frac{B}{\left(\sum_{i} \lambda_{i}+\sum_{m} m_{m}\right)^{\eta_{b}}} .
$$

$B$ is total government spending on public goods, and $\eta_{b} \geq 0$ measures to what extent there are congestion externalities in its provision. In particular, for $\eta_{b}=0$, the public good would be a pure public good, and for $\eta_{b}=$ 
1 , only per-person spending on it would be relevant. By setting the value $\eta_{b} \in(0,1)$, we allow for some returns to scale in public goods provision.

\begin{tabular}{|c|c|c|}
\hline Parameter & Value & Description \\
\hline$\sigma$ & 1.0 & $\begin{array}{l}\text { Elasticity of intertemporal } \\
\text { substitution }\end{array}$ \\
\hline$\gamma_{g}$ & 1.3 & CES parameter public goods \\
\hline$d_{g}$ & 0.5 & Weight public good \\
\hline$\beta$ & 0.5987369392383787 & Discount factor \\
\hline $\bar{b}$ & 0.05 & $\begin{array}{l}\text { Subsistence level of public } \\
\text { goods }\end{array}$ \\
\hline$\delta_{k}$ & 1.0 & Depreciation rate \\
\hline$\omega_{h}$ & 0.0 & $\begin{array}{l}\text { Skilled agents' unskilled } \\
\text { endowment }\end{array}$ \\
\hline$t_{k}^{*}$ & 0.2 & Foreign capital tax rate \\
\hline$\eta_{b}$ & 0.9 & $\begin{array}{l}\text { Congestion in public goods } \\
\text { use }\end{array}$ \\
\hline$n_{u}$ & 1.0 & Labor endowment unskilled \\
\hline$n_{h}$ & 1.0 & Labor endowment skilled \\
\hline$n_{u, m}$ & 1.0 & $\begin{array}{l}\text { Labor endowment unskilled } \\
\text { migrants }\end{array}$ \\
\hline$n_{h, m}$ & 1.0 & $\begin{array}{l}\text { Labor endowment skilled } \\
\text { migrants }\end{array}$ \\
\hline$p_{w}^{*}$ & 1.5 & $\begin{array}{l}\text { Relative price of goods on the } \\
\text { world market }\end{array}$ \\
\hline$P_{w}$ & 1.0 & Price level abroad \\
\hline
\end{tabular}




$\begin{array}{lll}A_{w} & 1.0 & \text { MFP final goods abroad } \\ \alpha_{x}^{w} & 0.5 & \text { World market share of } \mathrm{x} \\ r^{*} & 3.321942375150668 & \text { Interest rate abroad } \\ \xi & 0.0 & \text { Default risk dependents } \\ \mu_{u} & 0.0 & \text { Cost of curbing unskilled } \\ & & \text { migration } \\ \mu_{h} & 0.0 & \text { Cost of curbing skilled } \\ & & \text { migration } \\ \mu_{h u} & 0.0 & \text { Cost of sorting migrants } \\ \Delta_{y} & 0.01 & \text { Trade wedge } \\ \Delta_{k} & 0.01 & \text { Capital wedge } \\ \gamma & -0.30000000000000004 & \text { Exponent on public good } \\ y & -1.6666666666666665 & \text { Modified weight }\end{array}$

\section{Parameters relating to domestic agents}

$\begin{array}{cccl}\text { Parameter } & \text { Unskilled } & \text { Skilled } & \text { Description } \\ \lambda_{i} & 0.5 & 0.5 & \text { Initial population } \\ \theta_{i} & 0.1 & 1.0 & \begin{array}{l}\text { Elasticity of } \\ \text { immigration }\end{array} \\ \phi_{i} & 0.05 & 0.05 & \text { Probability of retiring } \\ -{ }^{\wedge} U i * & -10.0 & -9.0 & \text { Reference utility if } \\ & & & \text { migrating abroad } \\ z_{i}^{*} & 0.5 & 0.5 & \text { Elasticity of } \\ & & & \text { emigration }\end{array}$




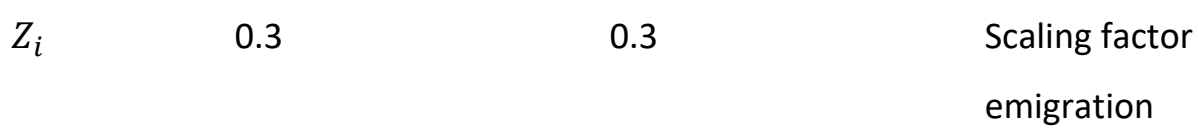

Parameters relating to potential immigrants

$\begin{array}{clll}\text { Parameter } & \text { Unskilled } & \text { Skilled } & \text { Description } \\ Z_{m} & 1.0 & 1.0 & \begin{array}{l}\text { Scaling factor } \\ \text { immigration }\end{array} \\ & & & \text { Elasticity of } \\ Z_{m} & 0.5 & 0.5 & \text { immigration } \\ & & & \text { Reference utility of } \\ U_{m}^{*} & -2.255 & -2.145 & \text { immigrants }\end{array}$

\section{Parameters relating to production structure}

\begin{tabular}{|c|c|c|c|c|c|}
\hline \multirow[b]{2}{*}{$g=$} & \multicolumn{3}{|c|}{ Factor shares } & \multicolumn{2}{|c|}{ Other parameters } \\
\hline & $\begin{array}{l}\text { Unskilled } \\
\text { labor }\end{array}$ & Skilled labour & Capital & $\operatorname{MFP}\left(A_{g}\right)$ & $\begin{array}{l}\text { Demand } \\
\text { share }\left(\alpha_{g}\right)\end{array}$ \\
\hline$x$ & 0.3 & 0.4 & 0.3 & 9.0 & 0.5 \\
\hline$y$ & 0.33 & 0.33 & 0.34 & 9.0 & 0.5 \\
\hline
\end{tabular}

\section{Other parameters}

Note: Aan additional layer of production is inserted: Unskilled labor is transformed into unskilled labor services at a rate of 1:1, whereas skilled labor is transformed into skilled labor services at a rate 1:1.5. This ensures that the skilled wage is higher than the unskilled wage. In effect, this is similar to changing $n_{h}$ to 1.5 , but reporting $w_{h} n_{h}$ as the effective wage. 


\section{References}

Bentley AF. 1908. The Process of Government: A Study of Social Pressures. Chicago: Univ. Chicago Press

Borjas, George J. 1987. "Self-Selection and the Earnings of Immigrants." American

Economic Review 77, no. 4: 531-53.

Borjas, G J (2003), “The Labor Demand Curve is Downward Sloping: Reexamining the Impact of Immigration on the Labor Market,” The Quarterly Journal of Economics 118(4): 1335-1374. Card, D (2001), “Immigrant Inflows, Native Outflows, and the Local Labor Market Impacts of Higher Immigration,” Journal of Labor Economics 19(1): 22-64.

Card, D (2005), “Is the New Immigration Really So Bad?”, The Economic Journal 115(507).

Cremer Helmuth and Catarina Goulão (2014), “ Migration and Social Insurance,” Louvain Economic Review Volume 80, Issue 1, pp. 5-29.

Disney, Richard (2007) “ Population ageing and the size of the welfare state: Is there a puzzle to explain?,” $\quad$ European Journal of Political Economy, Volume 23, Issue 2, June 2007, Pages 576577.

Dustmann, Christian , and Tomasso Frattini, (2014), “The Fiscal Effects of Immigration to the UK,” Economic Journal, 124(580).

Dustmann, C, U Schonberg, and J Stuhler (2017), “Labor Supply Shocks, Native Wages, and the Adjustment of Local Employment,” The Quarterly Journal of Economics 132(1): 435-483. 
Facchini, Giovanni, Assaf Razin, and Gerald Willman, (2004), “Welfare Leakage and

Immigration Policy,” CESifo Economic Studies, Vol. 50, 4/2004.

Foged, M, and G Peri (2016), “Immigrants' Effect on Native Workers: New Analysis on Longitudinal Data,” American Economic Journal: Applied Economics 8(2): 1-34.

Freeman, G. 1995. 'Modes of immigration politics in liberal democratic states'. International Migration Review, 29(4): 881-902.

Frenkel, Jacob, Assaf Razin, and Efraim Sadka (1991), “Basic Concepts of International Taxation”, NBER Working Paper No. 3540.

Gimpel, J. and Edwards, J. 1999. The Congressional Politics of Immigration Reform, Boston: Allyn \& Bacon.

Grogger, Jeffrey, and Gordon H. Hanson. 2011. "Income Maximization and the Selection and Sorting of International Migrants." Journal of Development Economics 95, no. 1: 42-57.

Haus, L. 1995. 'Openings in the wall: transnational migrants, labor unions, and US immigration policy'. International Organization, 49(2): 285-313.

Joppke, C. 1999. Immigration and the Nation-State: The United States, Germany, and Great Britain, Oxford: Oxford University Press.

Key, V. (1942). Politics, Parties and Pressure Groups, New York: Thomas Y. Crowell.

O’Rourke, Kevin (2003), “Heckscher-Ohlin Theory and Individual Attitudes Towards Globalization,” NBER Working Paper No. 9872.

Ottaviano, G I, and G Peri (2012), “Rethinking the Effect of Immigration on Wages,” Journal of the European Economic Association 10(1): 152-197.

Razin, Assaf (2021), Globalization, Migration, and Welfare State: Understanding the Macroeconomic Trifecta, Pelgrave macmillan. 
Razin, Assaf, Efraim Sadka and Phillips Swagel (2002a), "The Aging Population and the Size of the Welfare State," Journal of Political Econ omy, 110, pp. 900-918.

Razin, A., E. Sadka, and P. Swagel (2002b). Tax burden and migration: A political economy theory and evidence. Journal of Public Economics 85, 167-190.

Razin, Assaf and Jackline Wahba, (2015), "Welfare Magnet Hypothesis, Fiscal Burden, and Immigration Skill Selectivity,” Scandinavian Journal of Economics, Volume117, Issue 2, April 2015, Pages 369-402.

Scheve, K. and Slaughter, M. 2001. 'Labor market competition and individual preferences over immigration policy'. The Review of Economics and Statistics, 83(1): 133-45.

Truman, D. (1951).The governmental process. New York: Alfred A. Knopf. 